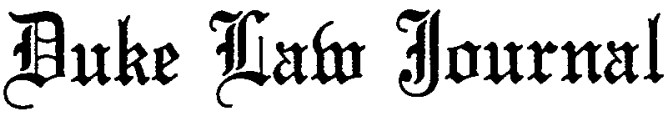

\section{STATUTORY REGULATION OF INSIDER TRADING IN IMPERSONAL MARKETS}

\author{
DenNis S. KaRJALA*
}

Insider trading oceurs when certain persons, through their position in a corporation or their relationship to it, acquire material, nonpublic information that relates to the value of the corporation's securities and trade on it in order to profit when the information is eventually disclosed. Notwithstanding a respectable argument to the contrary, ${ }^{1}$ most courts and commentators agree that insider trading is undesirable and must be regulated by law. ${ }^{2}$ Although the regulation of insider trading in impersonal markets has received considerable attention, ${ }^{3}$ one analytical point has been largely ignored that nevertheless has significant policy imphications for any atteinpt to rationalize the law of insider trading

* Professor of Law, Arizona State University. B.S.E. 1961, Princeton University; M.S. 1963, Ph.D 1965, University of Illinois; J.D. 1972 University of California (Berkeley).

1. H. MANNe, INSIDER TRAdING aNd the Stock Market (1966); Manne, Economic Aspects of Required Disclosure under Federal Securities Laws, in WALl STREET IN TRANSITION (1975). For a thorough analysis of this and related issues see Dooley, Enforcement of Insider Trading Restrictions, 66 VA. L. REv. 1 (1980).

2. The regulation of insider trading presupposes that one can determine who is an insider, when insider trading occurs, and how to ineasure the insider's unfair profit. Ratner, Federal and State Roles in the Regulation of Insider Trading, 31 Bus. LAw. 947, 947 (1976). The American Law Institute's Federal Securities Code (FSC) gives considerable guidance here, see FED. SEC. CODE $\S \S 1603(\mathrm{a})-(\mathrm{b}), 1703(\mathrm{~b}), 1708(\mathrm{a})-(\mathrm{b})(1980)$, although some questions remain. $C f$. Wolfson, Chiarella and the Federal Securities Code, 4 CORP. L. REv, 249, 252-53 (1981) (arguing that the FSC remains somewhat unclear on certain questions of tippee liability). The FSC's broad definition of an "insider," which encompasses virtually anyone who has privileged information by reason of a relationship with the issuer, as well as tippees of such persons, is the best proposed to date. See FED. SEC. CODE \& 1603(b) (1980).

3. The term "impersonal markets" refers to the national stock exchanges and to at least the relatively active portions of the over-the-counter market. Impersonal inarket transactions contrast with face-to-face transactions, in which buyer and seller negotiate directly with one another. The FSC defines an impersonal unarket transaction as one that "is effected in a nianner that would make the matching of buyers and sellers substantially fortuitous." FED. SEC. CODE $\$ 1702$ (b) \& Comment 4 (1980). For a discussion of some of the ramifications of this anonymity, see infra notes $16-17$ and accompanying text. 
through statutory reform. ${ }^{4}$ Few courts or commentators, if any, have realized that the goals of a system that regulates imsider tradimg necessarily differ depending on whether the corporation in question has a legitimate business reason for keeping the material information secret. The failure to distinguish these varying goals may be one cause of the continuing disagreement over policy that surrounds the prospect of statutory reform. Furthermore, confusion over the proper goals of imsider trading regulation has produced a scheme for regulating insider trading in the Federal Securities Code $^{5}$ (FSC) that is both unnecessarily complex and actually subversive of important regulatory ends.

Careful consideration of the possible goals of insider trading regulation shows that certain goals are either irrelevant or impossible to achieve if the corporation has a legitimate reason for nondisclosure. Moreover, even if there is no legitimate reason for secrecy, the various theoretically correct goals of insider tradimg regulation are not equally feasible in practice. In its attempt to establish a rational framework to analyze the insider trading problem, this article begins with a brief discussion of the various goals that unust be considered in developing a regulatory scheme. The relative importance of each goal is then established by examining its legitimacy and feasibility, both when the corporation has a good reason for nondisclosure and when it does not. After estabhishing the appropriate goals in each type of circumstance, this article examines the two inost widely advocated schemes of private enforcement to determine which is more rationally related to these goals and will most efficiently effect them.

These considerations demonstrate that, in inost circuunstances, compensation is an inappropriate goal of insider tradimg regulation. Moreover, even in those circuinstances in which compensation is theoretically justified, it is either impossible to achieve or conflicts with other, inore important goals. Because in all circumstances compensation of individual shareholders is thus either inappropriate or impossi-

4. Parts XVI and XVII of the FSC pertain to insider trading. See infra text accompanying notes 42-49. At present, insider trading is regulated most generally under rule 10b-5, 17 C.F.R. $\$ 240.10 \mathrm{~b}-5$ (1981), and the rule's judicially implied private right of action for certain injured traders. The corporate cause of action advocated herein, see infra text accompanying notes 53-64, would be barred by the purchaser/seller requirement of rule 10b-5, which was reaffirmed in Blue Chip Stamps v. Manor Drug Stores, 421 U.S. 723 (1975), because the corporation cannot be a purchaser or seller of its own securities during the secrecy period without itself violating the antifraud rules. Ratner, supra note 2, at 960; Comment, $A$ Re-Evaluation of Federal and Siate Regulation of Insider Trading on the Open Securities Market, 58 Wash. U.L.Q. 915, $942-43$ (1980). For a general treatment of the problem of applying rule 10b-5 to insider trading, see Dooley, supra note 1; Wang, Trading on Material Nonpublic Information on Impersonal Markets: Who Is Harmed, and Who Can Sue Whom Under SEC Rule 10b-5?, 54 S. CAL. L. Rev. 1217 (1981).

5. FED. SEC. CODE (1980). 
ble, this article concludes that the sole private claim against the insider for damages ${ }^{6}$ should lie in the corporation, whether or not the corporation had a legitimate reason for nondisclosure at the time of the illegal trading. This specific conclusion may remain open to debate, but the analysis of the goals of insider trading regulation in varying circumstances clarifies the issues around which the debate should revolve.?

\section{- I. Goals of Insider Trading Regulation}

There are several possible purposes for insider trading regulation. If anyone is injured as a result of insider trading, the law should provide a means by which the injured party can obtain redress; therefore, compensation of injured parties is arguably an important goal in constructing a regulatory scheine. A second goal follows from the widely held assumption that insider trading in securities of publicly lield coinpanies, which almost invariably takes place in impersonal markets, injures the market by causing investors to lose confidence in the integrity of the system. ${ }^{8}$ No one has provided a formula for ineasuring this supposed injury to the market, and the allegations of harm may reflect nothing more precise than the moral position that insider trading is bad and must be regulated. Nevertheless, the assumption that such injury occurs makes deterrence a fundamental objective. Third, insofar as insider trading is considered simply wrongful activity, punishment of the wrongdoers and disgorgement of their unfair profits becoine important

6. In this context the word "damages" does not imply that the recipient has been injured or has sufiered a loss; it is simply shorthand for whatever monetary award the law may give to a private plaintiff.

7. The specific recommendation of this article-that a private right of action for damages should be recognized only in the corporation whose shares were traded-has been made before, but on different analysis. See Knauss, Disclosure Requirements-Changing Concepts of Liability, 24 Bus. LAw. 43, 58-59 (1968) (recommending that the corporate claim supplement the possibility of enforcement action by the SEC, with payment of unfair insider profits to the corporation in either case); Ratner, supra note 2, at 957-60; Sommer, Rule 10b-5: Notes for Legislation, 17 W. RESERVE L. REv. 1029, $1047-49$ (1966); Comment, Fashioning a Lid for Pandora's Box: A Legitimate Role for Rule 10b-5 in Private Actions Against Insider Trading on a National Stock Exchange, 16 U.C.L.A. L. REv. 404, 415 (1969) [hereinafter cited as Comment, Pandora's Box]; Comment, supra note 4 , at $942-43$.

8. Two cases that differ sharply on the degree of civil hability insider traders should incur agree, nevertheless, that protecting the "integrity of the market" is a key feature of rule 10b-5's prohibition of insider trading. Compare Shapiro v. Merrill Lynch, Pierce, Fenner \& Smith, Inc., 495 F.2d 228, 237 (2d Cir. 1974) with Fridrich v. Bradford, 542 F.2d 307, 318 (6th Cir. 1976), cert. denied, 429 U.S. 1053 (1977); see also Branson, Discourse on the Supreme Court Approach to SEC Rule IOb-S and Insider Trading, 30 EMORY L.J. 263, 295-97 (1981); Rapp, Fridrich v. Bradford and the Scope of Insider Trading Liability Under SEC Rule 10b-5: A Commentary, 38 OHIo ST. L.J. 67, 70 (1977); Note, Damages to Uninformed Traders for Insider Trading on Impersonal Exchanges, 74 Colum. L. REv. 299, 317 (1974); Comment, Insider Trading Without Disclosure-Theory of Liability, 28 Oнго ST. L.J. 472, 479 (1967). 
aims of the regulatory system. Fimally, inducing rapid public disclosure of material information is a fourth possible goal of any system that regulates insider trading.

These goals are not all feasible, or even appropriate, in all circumstances. For example, the goal of rapid public disclosure of material information is irrelevant when the corporation has a legitimate business purpose for secrecy. Nor is compensation an appropriate regulatory goal under such circumstances because a compensatory award presupposes a causal relationship between the wrongful act of trading and the injured party's loss. If a corporation lias a legitimate business purpose for keeping inaterial information secret, insider trading on that information causes no identifiable injury to those persons who have been the primary subject of judicial and academic concern-persons who trade in the opposite direction from the imsider before the news becomes public ("losing market traders" or "market losers"). 9 To the extent that losimg market traders make independent decisions to enter the market in the security at the then-prevading narket price, they do not suffer any mjury that can be causally related to the insider's wrongful act. The requisite causal relationship does exist if the losing market trader's transaction is induced by the insider's activity ("induced traders"), ${ }^{10}$ but it is not possible as a practical matter to identify such traders. Similarly, persons who would liave traded in the same direction as the insider, but whose potential purchases or sales were preempted by the insider's trading activity ("preempted traders"), suffer losses caused by imsider trading. Again, lowever, there is no reliable method for identifying such traders. Finally, there are those traders who make an independent decision to trade in the same direction as the insiders and who fortuitously reap benefits froin the subsequent price change ("winning market traders"). Winning market traders are identifiable, and, to the extent that imsider trading affects the market price before disclosure of the secret information, they suffer losses in the form of lower fortuitous gains than they would have made had the insiders abstained from trading. 1 However, the amount of their loss is not easily identified, nor does it bear any relationship to the amount of the insiders' profits.

Thus, when the corporation has a legitimate business purpose for nondisclosure of material information, insider trading on the information causes no mjury to most losing market traders and ijjures unidentifiable induced and preempted traders, as well as identifiable winning

9. See infra text accompanying notes 24-31.

10. The terminology "induced" and "preempted" traders is that of Professor Wang. See Wang, supra note 4, at $1230-40$.

11. See infra notes $26,32-34$ and accompanying text. 
market traders, to an undeterminable extent. Under these circumstances, compensating innocent investors for their losses is either unwarranted or impossible and cannot stand as an appropriate goal of the regulatory systein. This conclusion has specific implications for the design of a regulatory scheme: the goal of compensation does not justify a statutory civil action for damages when the corporation has a legitimate business reason for secrecy.

One 'might still want to allow a civil action for damages against inside traders in service of some of the other regulatory goals. Deterrence and punishment, for example, could perhaps be increased by authorizing losing market traders, or soine subset of thein, to sue the illegally trading insiders for statutorily defined money damages. If deterrence and punishment are its goals, however, the regulatory scheme ought to be rationally related to their achievement. Some courts, ${ }^{12}$ with approval by commentators, ${ }^{13}$ have awarded to losing market traders damages measured by the difference between the uninformed investor's transaction price and the value of the security after the information becaine public. Such a system can easily result in a total award many times greater than the insider's illegal profit. The award is not merely a windfall to losing inarket traders whose losses are causally unrelated to the wrong; it completely overwhelms any purported disgorgement principle and is without basis im any rational theory of punishment, because the damages bear no relationship to the insider's wrongful acts. ${ }^{14}$

When a corporation has no legitimate purpose for nondisclosure of material information, insider trading on the information directly causes injury to identifiable losing market traders in some cases. ${ }^{\text {is }}$

12. See Elkind v. Liggett \& Myers, Inc., 472 F. Supp. 123 (S.D.N.Y. 1978), rev'd, 635 F.2d 156 (2d Cir. 1980); Shapiro v. Merrill Lynch, Pierce, Fenner \& Smith, [1975-1976 Transfer Binder] FED. SEC. L. REP. (CCH) I 95,377 (S.D.N.Y. Dec. 9, 1975); Astor v. Texas Gulf Sulphur Co., 306 F. Supp. 1333 (S.D.N.Y. 1969). Because both Shapiro and Astor involved motions concerning the validity of plaintiff' claims against the trading insiders, neither court had to take the final step of actually imposing liability in excess of defendants' wrongful gains. Elkind did raise this problem, however, in a particularly poignant setting. It was an action against the company for tipping by its officers to outsiders who traded. Thus, the defendant was two levels removed froin the actual profiteering. Although there were tippee profits of approximately thirty to forty thousand dollars, the district court awarded damages to all persons trading in the opposite direction during the secrecy period, untroubled that the total award might reach $\$ 740,000$. $472 \mathrm{~F}$. Supp. at 135 . Such "draconian damages," however, were too much even for the Second Circuit, 635 F.2d at 170, which did not change the standards for membership in the plaintiff class but did limit total damages to the amount of the tippees' unfair profit. Id. at 172-73. Thus, the Second Circuit's approach is now essentially that of the FSC. See infra text accompanying notes 42-49.

13. See generally Rapp, supra note 8.

14. See Elkind v. Liggett \& Myers, Inc., 635 F.2d 156, 170 (2d Cir. 1980); Dooley, supra note 1 , at 22-24, 66 .

15. See infra text accompanying notes $69-72$. 
Compensation of these losses is therefore an appropriate theoretical goal of the regulatory scheme. However, most of these losses represent gams, not to the insider, but to fortuitous winning market traders who have committed no wrongful act. As a result, requiring the insider to recompense losing traders for the full amount of their damages may seem overly punitive despite the causal relationship. An alternative regulatory scheme might limit the class of private claimants to losing market traders who, quite fortuitously, happen to be "matched" with the insider by the exchange specialist or market maker and who are thereby in direct privity of contract with the insider. This scheme restricts maximuin theoretical damages to the amount of the insider's wrongful profit, but suffers from a disconcerting arbitrariness in that those persons who turn out to be in privity of contract with the insider cannot be rationally distinguished from any other losing market traders as to how or whether they suffered losses. ${ }^{16}$ Furthermore, even a system that could actually insure hability up to the amount of the insider's wrongful profit ${ }^{17}$ might be an insufficient deterrent because the worst that could happen to the inside trader would be that he would lose his profit, plus his costs of suit, if he were caught. 18

Many commentators have sensed these problems, but to resolve them they usually implicitly assume that the corporation in question has a justifiable reason for secrecy during the period in which the insiders are trading in the market. They then conclude-quite correctly on the basis of their assuniption-that the absence of demonstrable harm to individual losing market traders implies that the proper goals of the regulatory scheme are deterrence, punishment, and general protection of the integrity of the nuarket. ${ }^{19}$ That the goals theinselves might differ depending on the circumstances of the company and the type of infor-

16. Comment, Pandora's Box, supra note 7, at 408-09.

17. The difficulty of "matching" buyers and sellers who trade on a national securities exchange makes it unlikely that many people who could be said to have traded directly with the imsider will ever know they did and bring suit. Id.

18. See, eg., Note, Common Law Corporate Recovery for Trading on Non-Public Information, 74 Colum. L. Rev. 267, 296 (1974); Comment, Pandora's Box supra note 7, at 417. See infra text accompanying notes $39-41$.

19. E.g., Note, supra note 8, at 310-11; Note, Limiting the Plaintiff Class: Rule 106-5 and the Federal Securities Code, 72 Mich. L. REv. 1398, 1429 (1974); Comment, Pandora's Box, supra note 7, at 412; Comment, Civil Liability Under Section 1OB and Rule 10B-5: A Suggestion for Replacing the Doctrine of Privity, 74 YALE L.J. 658, 677-79 (1965) [hereinafter cited as Comment, Civil Liability]. The absence-of-liarm analysis is correct only insofar as it applies to losing market traders who are not induced traders. Induced traders, as well as preempted traders, are harmed as a result of insider trading, see supra text accompanying note 10, but only Professor Wang has made this distinction. See infra notes 27-28 and accompanying text. Winning market traders also suffer liarm, but the possibility of recompensing their losses is rarely discussed. See infra notes 3234 and accompanying text. 
mation involved has received little or no consideration. Nevertheless, identifiable individual losing market traders are in fact harmed when the corporation unjustifiably delays disclosing material information. In these circumstances compensation is arguably a primary goal of regulation. Because the goals of regulation are different when a corporation has a legitimate reason for secrecy and when it does not, distinguishing these cases will clarify the argument over the proper means of regulation and point toward a solution that is rationally related to all appropriate social goals.

\section{Regulation of Insider Trading When the Corporation Has a Justifiable Reason for SeCrecy}

\section{A. Appropriate Regulatory Goals.}

The internal machinery of large corporations often generates material information that, for legitimate business purposes, cannot immediately be disclosed to the public. The classic example appears in $S E C$ v. Texas Gulf Sulphur Co..$^{20}$ In that case, the company was engaged in delicate negotiations for mineral rights, and disclosure of the exploratory discoveries would have adversely affected its bargaining position. The much-heralded "disclose or abstain" rule of Texas Gulf Sulphur recognizes that there are legitimate reasons for secrecy; thus the rule condones nondisclosure as long as the insider abstams from trading. ${ }^{21}$ Courts have recognized that harm can flow as easily from public release of unverified or incorrect reports as from failure to disclose correct reports of new developments, and they have generally held that, in the absence of insider trading, the timing of disclosure is a natter within management's discretion. ${ }^{22}$

Determining the circumstances in which a corporation has a legitinate busimess need for secrecy, and separating them from those in which it does not, is a very difficult problem. ${ }^{23}$ Cominentators agree,

20. 401 F.2d 833 (2d Cir. 1968), cert. denied, 394 U.S. 976 (1969).

21. Id. at 848; see also In re Investors Mgt. Co., 44 S.E.C. 633, 646 (1971); Brudney, Insiders, Outsiders, and Informational Advantages Under the Federal Securities Laws, 93 HARv. L. REv. 322, 337-38 (1979); Comment, Pandora's Box, supra note 7, at 405.

22. See Financial Indus. Fund, Inc. v. McDonnel Douglas Corp., 474 F.2d 514, 518 (10th Cir.), cert. denied, 414 U.S. 874 (1973); SEC v. Texas Gulf Sulphur Co., 401 F.2d 833, 850 n.12 (2d Cir. 1968), cert. denied, 394 U.S. 976 (1969); Elkind v. Liggett \& Myers, Inc., 472 F. Supp. 123, 127-28 (S.D.N.Y. 1978), rev'd in part on other grounds, 635 F.2d 156 (2d Cir. 1980); Segal v. Coburn Corp. of Am., [1973 Transfer Binder] FED. SEC. L. REP. (CCH) If 94,002 at 94,020 (E.D.N.Y. April 30, 1973).

23. It is precisely this difficulty that makes implication of a general obligation to disclose under rule 10b-5 so troublesome. Compare Bauman, Rule 10b-5 and the Corporation's Affirmative Duty to Disclose, 67 GEo. L.J. 935, 989 (1979) (arguing in favor of rule 10b-5 liability for nondisclosure absent a valid reason therefor, or at least a good faith effort to disclose) with Comment, 
however, that there is sometimes a legitimate need for secrecy, ${ }^{24}$ and some have argued that when nondisclosure is justifiable no losing market trader is harmed by insider trading. ${ }^{25}$ These commentators reason that when the secret information ultimately becomes public the market price of the securities will change, resulting in sudden losses for some traders and sudden gains for others. Because the nondisclosure is justifiable, however, the public unavailability of the secret information is independent of the insider's decision to trade on it. Therefore, the losing market traders' losses are caused solely by their own independent investment decisions to buy or sell at the particular times they did. In fact, the argument goes, insider trading activity can only lelp losing market traders. For exainple, if insider purcliases based on favorable secret information have any effect on the market, it inust be to increase the price. As a consequence, losing inarket traders who have decided independently to sell their shares might receive a slightly higher price than they would receive had the insider trading not occurred. The fortuitous gains by the winning inarket traders (those who trade in the same direction as the insider) will be correspondingly reduced. Similarly, if insider selling activity based on adverse inside information has any effect on the market, it will decrease the price, and any inarket trader who has independently decided to purchase the securities in question at that time may pay a lower price. ${ }^{26}$ Insider trading, insofar as it affects the market, causes it to reflect the value of the secret information, and any losing inarket trader's loss results froin the legitimate nondisclosure of the information by the corporation, rather than from the insider trading activity.

Professor Wang has deinonstrated, however, that this arguinent is not quite correct. ${ }^{27}$ Even if most outsiders' investment decisions are truly independent of insider trading activity, in the sense that the same decisions would have been inade notwithstanding any price clianges resulting from insider purchases or sales, they cannot all be independent. Professor Wang's "Law of Conservation of Securities"28 states that the securities purchased by insiders are no longer leeld by outsiders.

Disclosure of Material Inside Information: An Affirmative Corporate Duty?, 1980 ARIz. ST. L.J. 795, 805-08 (arguing against a rule requiring disclosure absent a valid business purpose, on the grounds that the vagueness of the business purpose test makes the potentially astronomical liability unfair, that it might force premature disclosure to the detriment of the corporation, and that it would be unlikely in any event to improve corporate disclosure).

24. E.g., Dooley, supra note 1, at 32, 63-64.

25. Id. at 33; Note, supra note 8, at 306; Comment, Pandora's Box, supra note 7, at 409-10; Comment, Civil Liability, supra note 19, at 675-76.

26. See Ratner, supra note 2 , at 949 , 956; Note, supra note 8, at 306 n.62.

27. Wang, supro note 4 , at $1230-40$.

28. Id. at 1234-35, 1248. 
Therefore, some outside person or group does not participate in the benefits of the subsequent price rise when the good news is announced. By carefully considering the actual dynamics of trading transactions in impersonal markets, Professor Wang significantly refines the analysis of who is harmed by insider trading. He shows that the persons injured by insider tradimg activity are either induced traders, preeinpted traders, or some coinbination thereof. If these injured persons could be identified; it would seein appropriate to permit them to sue the insiders for damages measured by the difference between the price at which they traded-or would have traded but for the preeinption -and the price after the news becomes public. ${ }^{29}$ Unfortunately, identification of those injured requires subjective motivational analysis not only of all actual traders, but even of potential traders - clearly an impossible task. ${ }^{30}$ To permit all losing market traders to sue for differential damages would allow compensation to induced traders, but it would also give a cause of action the large group of traders whose investinent decisions were truly independent of the insider trading activity. Such a remedy would not only be overinclusive but probably overly punitive

29. This analysis also provides a theoretical basis for limiting damage claims against the insider to the amount of his profit. On good news, the insider withdraws from the market some number of shares at some low price. Absent the insider trading, those shares would be held by the persons selling to the insider, by persons who would have bought the shares had they not been preempted by the insider's purchase, by persons who would not have sold unless induced by the insider purchases, or by some combination of such persons. None of these persons are identifiable; nevertheless they were injured because they either sold or failed to buy at the price paid by the insiders. (Of course, many of the preempted traders, had they been able to buy, might have resold before the good news was made public. But the persons buying from them, or their transferees, would have made up the difference between the preempted traders' potential profit and the inside traders' actual profit, omitting transaction costs.) The total loss to this large group 'of unidentifiable outsiders who are mjured by the insider trading activity must therefore be very close to the insiders' profit. In fact, deviations from exact congruence could seemingly come ouly froin induced selling losses caused by a generally increased volume in the seeurity resulting from the insider's initial activity. But this type of induced loss is very much like an ordinary imvestinent risk: to the extent that the shares are not acquired by an insider, they are presumably taken up by equally innocent induced purchasers; it is a zero sum game wherein innocent losses are offset by innocent gains. Purchases and sales can be and often are induced by unusual but legal market activity; therefore, this subset of induced losses arguably ought not be compensated. It is not market activity, as such, that is the focus of insider trading regulation, but rather the perceived unfairness of the insider's making a sure profit while all other investors are subject to risk. Focusing only on the shares the insider has removed from the market thus leads to the conclusion that the damages the insider causes to induced and preempted traders exactly equals the insider's profits.

30. See Wang, supra note 4 , at $1237,1251,1254$. Although some may question the strict interpretation of the purchaser/seller requirement under rule 10b-5 as applied to the specific facts of Blue Chip Stamps v. Manor Drug Stores, 421 U.S. 723 (1975) (a well-defined group of offerees was induced by a falsely pessimistic prospectus to reject an offer to purchase valuable stock), the rule certainly has merit in circaunstances that do not limit the number of persons who inight later claim that they wonld have acted differently had they had more, or more accurate, information. 
as well. It would, at the same time, be underinclusive by failing to provide for recovery by preempted traders although their losses are caused by imsider tradimg. ${ }^{31}$ Therefore, as theoretically desirable as it may be to provide a means to compensate those imjured by the wrongful activity-induced and preempted traders-the extreine difficulty of identifying these injured parties nnakes compensation an impossible goal.

Winning market traders are an identifiable group, and their losses are directly caused by insider trading. These traders make an independent investment decision ${ }^{32}$ to trade in the same direction as the insiders, and their fortuitous gains are therefore reduced by the amount that the imsider trading affects the price at which they trade. Unfortunately, compensation of this loss requires a measurement of the extent to which the insider trading activity actually affects the price, which is probably impossible to determine. ${ }^{33}$ Moreover, the hitigated cases show no inclination on the part of market winners to assert such claims agamst the insiders, and few if any commentators have shown any syinpathy for their plight. ${ }^{34}$ This attitude suggests that whatever inoral principle underhes the prohibition against insider trading, it is not aimed at protecting this class of investors. Compensation for their reduced winnings, therefore, is neither possible nor desirable, and the regulatory system need not be designed to compensate them.

If a corporation has a legitimate busmess purpose for keeping material information secret, and no insider trades on the information, all losses are the result of the legitimate nondisclosure - an ordinary inarket risk. The presence of insider trading does not affect the status of these losses, except when the insider activity induces the losers to trade

31. Wang, supra note 4 , at $1237,1251,1254$.

32. No induced market winner-one whose trade is induced by the increased activity that results from insider trading - has any complaint here. Absent the insider trading activity, these induced market winners would have no gains at all; they can hardly complain that their gains were reduced by the insider trading. Of course, to the extent that induced market winners exist, the independently trading market winners cease to be readily identifiable, which would be another reason for denying them any recovery. I assume, however, that the relative number of induced unarket winners is small.

33. Any losses suffered by the winners are caused by changes in market price resulting from the insider trading activity. There inay often be no measurable change, and in any event the loss bears no relationship to the amount of the insider's unfair profit. Therefore, granting a limitcd claim for the amount of the insider's profit (or some multiple thereof) to the winners is no more rational than granting it to the losers. A claim by the winners for actual damages makes more seuse theoretically, although problems of proof (showing the effect of the insider trading activity on market price) might make it impractical. This may be why market winners have not heretofore asserted such claims.

34. To give a private disgorgement claim against the insiders to the market winners would add insult to the investunent-risk injury suffered by the inarket losers. 
or preempts their trading. Yet it is not possible to identify these losers and compensate their losses. Therefore, compensation is simply not an appropriate goal of insider trading regulation when the corporation has a legitimate business purpose for keeping the material information secret. It is also obvious that rapid public disclosure of the information cannot be a goal of the regulatory system in these circumstances, as it would contradict the hypothesis that the corporation needs to keep the information secret. Nor has anyone demonstrated that the supposed imjury to the market caused by imsider trading can be even roughly measured by the extent of the losing market traders' losses. ${ }^{35}$ Only deterrence, disgorgement of unfair profits, and punishment remain plausible goals of the regulation of insider trading in impersonal markets when the corporation has justifiable business reasons for secrecy. Therefore, the better regulatory scheme will be one that provides an optinal combination of deterrence, disgorgement, and punishment, regardless of any compensatory effects.

\section{B. Aiming at the Goals Through Private Rights of Action.}

The goals of deterrence, disgorgement, and punishment are served only in proportion to the efficiency of the enforcement mechanism. In other words, the more likely it is that insider trading will result in a lawsuit, the more likely it is that the insider will be punished and will have to disgorge his unfair profit; the degree of deterrence will presun1ably be higher as well. Therefore, evaluating various regulatory schemes is simply a inatter of determining which would result in the greatest degree of efficient enforcement. ${ }^{36}$ Assuming that a private claim is a desirable supplement to the various enforcement mechanisms available to the government, ${ }^{37}$ one may compare the approach of the FSC, which permits losing market traders to bring a private action for a limited amount, with a scheme that gives a private claim for the same

35. Indeed, no one has defined the supposed injury in terms sufficiently concrete to permit even a conceptual estimate of the damages. One indication of the difficulty is that a significant number of innocent outsiders profit, albeit fortuitously, from the delay in disclosure. The narket losers' anger and frustration inay undermine their confidence in the market, but this harm may be offset by the satisfaction of the fortuitous market winners and their corresponding enthusiasin for the market system. There is no formula by which to measure and compare these hypothetical effects. Morcover, the losers' anger is most properly directed inward, because most of their losses are the result of their own investment decisions. See supra notes 25-26 and accompanying text. It is not clear that the integrity of the market is increased by redirecting that anger toward trading insiders, falsely implying that their illegal actions caused the losses.

36. See Note, supra note 8 , at 315 .

37. Egregious cases, of course, may call for criminal sanctions, but these sanctions seem clearly separable from the civil regulatory scheme. 
limited amount solely to the corporation, to determine which would result in more efficient enforcement. ${ }^{38}$

Whether the cause of action lies with the individual or the corporation, determination of the proper amount of the claim remains largely a subjective inatter. Disgorgement of the insider's unfair profit-measured by the difference between his transaction price and the value of the security after full disclosure, reduced perhaps by interim fluctuations caused by sources unrelated to the secret informationseems to be the minimum that almost any commentator on this subject would require. A scheme requiring no inore than disgorgement of the unfair profit, however, might not be a sufficiently strong deterrent to insider trading. The insider could trade in the loope that he would not be caught, knowing that even if he were caught his net loss would only be the cost of litigation. Many insiders might consider this a good gamble. Some commentators have therefore suggested that punitive damages should be available, ${ }^{39}$ and others have argued for inultiple damages, that is, private claims equalimg some inultiple of the amount of the insider's unfair profit. 40 The line between a system that provides too little deterrence and one that is overly punitive is not an easy one to draw. Absent better empirical evidence than is now available, where that line is placed may depend largely on one's view of just how bad insider trading really is. In this sense the decision may be essentially arbitrary. ${ }^{41}$ Assuming that the appropriate amount of the private claim has been decided and is fixed by some statutory formula, the

38. A third possibility that has received some support in the literature is to permit the SEC itself to recover the amount of the claim against the illegally trading insiders, partially on the theory that the regulatory cffort could finance itself once the SEC started collecting insider profits, perhaps in multiples. E.g., Note, supra note 8, at 316; see also Knauss, supra note 7, at 58-59; Ratner, supra note 2, at 954-55. The basic question is how to achieve the greatest degree of cnforcement, lowever, and it is far from clear that even a larger government agency could discover and sift through the myriad of potential violations as efficiently as private attorneys hoping to earn a contingency fee. See infra text accompanying notes $65-66$. Nor is it clear that the SEC would make better use of the inoney, especially any amounts in excess of its enforcement costs, than private parties who might reinvest it. Such a scheme could be an interesting experiment, but this article concentrates on the less radical approaches.

39. See Ratner, supra note 2, at 961-62; Note, supra note 18, at 295-96; Comment, Pandora's Box, supra note 7, at 417-20.

40. The changes to the official draft of the FSC, to which the SEC agreed, give the court discretion to increase damages up to 50\%. FeD. SEC. CODE \& 1708(b)(4)(C) (Supp. II 1981). See also Pozen, An Overview of the Proposed Code's Treatment of Private Causes of Action and Damages, 1 PACE L. Rev. 355, 364 \& n.33 (1981). A leading Japanese securities law scholar, who advocates deterrence of insider trading, increased compeusation to victims, and encouragement of rapid public disclosure, has similarly recommended a statute that would provide double damages plus an amount equal to $10 \%$ of the damages per day from the day the insider first trades until the information becomes public. Tatsuta, A Proposed Statute Regulating Insider Trading and Commentary Thereto, 746 Sнолномu 2, 7-8 (1976) (in Japanese).

41. Cf. Pozen, supra note 40, at 364 (pointing out that any specific limit on the damage inultiple will necessarily be arbitrary, but slould be large enough to provide a deterrent). 
question remains: who should be permitted to bring the civil action to recover that amount?

1. The FSC Approach and Its Problems. Section 1603(a) of the FSC $^{42}$ is the basic provision that makes insider trading unlawful in both face-to-face transactions and impersonal markets. An insider who violates section 1603(a) in an impersonal market is liable under section 1703(b) ${ }^{43}$.to all market traders who trade in the opposite direction from the day the insider first illegally trades until the information becomes generally available. Damages to each market trader are determined by the difference between the trading price and the value of the security a reasonable time after the information becomes public, ${ }^{44}$ but total damages are limited to the insider's profit, measured in the same way as the plaintiffs' losses. ${ }^{45}$ The FSC also provides for the consolidation of all actions against a single defendant ${ }^{46}$ and notice to all potential plaintiffs. ${ }^{47}$ Proration of the limited claim anong all plaintiffs ${ }^{48}$ is required unless the expense of proration appears unwarranted, in which case the anount of the claim goes to the corporation or to the Securities Investor Protection Corporation. ${ }^{49}$

Whatever degree of enforcenent the apportioned-claim approach of the FSC might achieve would not come without significant cost. First, the apportionment provision obscures the proper goals of the regulatory scheme by making it appear that compensation of trading

42. FED. SEC. CODE \& 1603(a) (1980).

43. Id. \& 1703(b).

44. Id \& 1708(a)-(b). The measure of damages is reduced to the extent "that the defendant proves that the violation did not cause the loss . . ." Id. $\$ 1708(\mathrm{~b})(2)$. This creates a potential loophole in the overall scheme of the FSC. The reduction of damages provided by section 1708(b)(2) arguably permits total escape from liability for insider trading because the insider trading as such does not cause identifiable injury to most losing market traders. See supra text accompanying notes 25-32. Of course, in order to carry his burden of proof, the defendant may have to prove that the plaintiffs are not induced traders, but this may be possible, at least to the extent that the plaintiffs respond honestly on deposition. At the very least, it might result in the disqualification of the named plaintiffs as class representatives and thereby retard the progress of the litigation. On the other hand, the number of persons who are eligible plaintiffs until disqualified may be so large that, with damages limited by section 1708(b)(3), many defendants may simply not raise the causation issue. In any event, given the general irrelevance of compensation to the class claim, there seems to be little justification for any causation defense as applied to section 1603(b).

45. FED. SEC. CODE § 1708(b)(3) (1980). But see supra note 40.

46. Id. \$1711(a)-(e).

47. Id. \&1711(h).

48. $I d . \& 1711(\mathrm{j})(1)$.

49. Id. \& 1711(j)(2)-(3). 
losses is-or even can be-a significant goal of the system..$^{50}$ The FSC goes through all the motions of a class action aimed at compensating losing market traders for their losses, notwithstanding the absence of any identifiable mjury related to the wrong. As with all class action hitigation, suits against inside traders under the FSC would require expensive and time consuming procedures for notice, collection, proof of claims, and distribution of apportioned damages. The immense recovery that motivates many class action lawyers to take on these procedural complexities, however, has been eliminated. Furthermore, the ainount eventually awarded to individual class members will usually be no more than a small part of their total losses. The small recovery results from the fact that most of these losses represent gain, not to the imsider, but to winning market traders who happened to be in the market during the secrecy period. The plaintiff class members are unlikely to feel that this is a satisfactory result.s1 Doubtless, losing investors will be disappointed when the secret information becomes public, but this is true whether or not insider trading has taken place. To revive the losers' hopes with all the publicity that surrounds class action litigation, only to dash them again later with a mere nominal recovery, may only serve to increase disappointment, ${ }^{52}$ and further undermine investor confidence in the securities markets.

50. The confusion over compensation as a goal of the system is exacerbated by the commentary to the FSC: "The theory, again, is compensation if practicable but in any event deterrence and avoidance of unjust enrichment." Id. \&1711(j), Comment 7(a).

51. Of course, doubling or trebling the damages will make the losing market traders feel better, but this alternative loses sight of the proper goals. Any multiple damages provision should serve the purpose of increased deterrence, not compensation. See supra note 41 and accornpanying text. If the proper object is to make the losers feel better, which is another way of saying they deserve compensation for their losses, there is no reason for stopping arbitrarily at some fraction. On the other hand, if the sole object is enforcement of the disgorgement penalty, any recovery by market losers must be considered wholly incidental to the enforcement mechanism. If the private action in market losers for limited damages has the defect that it increases grumbling because of nominal recovery, we should not compound the defect with the mistake of increasing the amount of the claim to an overly punitive level. The remedy rather is to eliminate the underlying cause of the grumbling in the first place, which is the unnecessary private claim in market losers who have not suffered from the wrong being rectified.

52. Their pecuniary disappointment will probably outweigh whatever subjective satisfaction, if any, they derive from being direct participants in punishing the insider via the class action. It is perhaps an open question whether the FSC approach ameliorates or exacerbates the disappointment problem. It revives the hopes of losing market traders through notice of, and participation in, the class action but permits the possibility of zero recovery where the amounts awarded to the small investors do not warrant prorating the claim. See supra text accompanying notes 48-49. Moreover, the drafters of the FSC do apparently visualize drawing some line between large and small claimants that would permit recovery of the apportioned amounts by large investors while ignoring the small investors. FED. SEC. CODE \& 1711(j) Comment 7(b) (1980). This provision certainly seems well designed to increase any latent feelings among small public investors that the law only takes care of the big guys. 
2. An Alternative Proposal: The Corporate Claim Approach. Instead of taking the FSC approach, a federal regulatory scheme could authorize a corporate cause of action against insiders who trade in the corporation's securities on the basis of privileged information when the corporation has a legitimate reason for secrecy. Section 1714 of the FSC, ${ }^{53}$ like section 16(b) of the 1934 Act, ${ }^{54}$ provides a corporate cause of action for the recovery of short-swing profits from a limited subset of inside traders. ${ }^{55}$ The alternative suggested here would apply the approach of section 16(b), but would authorize a corporate cause of action against all inside traders for the recovery of their illegal profits. It would at the saine time deny a private action for damages to losing inarket traders, at least when nondisclosure was justified by a legitimate busmess purpose. In effect, this corporate claim approach would codify the holding, if not the rationale, of Diamond $v$. Oreamuno. ${ }^{56}$ In Diamond the New York Court of Appeals allowed a corporate recovery through a shareholder's derivative suit against officers and directors who traded on inside information. The Diamond court reasoned that inside information is a corporate asset and that, by their abuse of this asset, the defendants breached their fiduciary duty to the corporation..$^{57}$ The court also conjectured that insider trading injures a corporation's reputation and thereby undermines the value of its securities. ${ }^{58}$ Proof of actual damage to the corporation is unnecessary under Diamond because the imderlying purpose of the disgorgement remedy is deterrence rather than compensation. 59

The Diamond doctrine has not been widely accepted; there are serious probleins with both the corporate asset theory and the hypothesis that insider trading dainages the corporation. ${ }^{60}$ In any event, a state

53. FED. SEC. CODE § 1714 (1980).

54. 15 U.S.C. $\$ 78 \mathrm{p}(\mathrm{b})(1976)$.

55. Following section $16(b)$, FSC section 1714 only applies where the inside trader is a director, an officer, or an owner of more than $10 \%$ of the shares of the corporation. FED. SEC. CODE $\$ \$ 605(a), 1714(a)$.

56. 24 N.Y.2d 494, 248 N.E.2d 910, 301 N.Y.S.2d 78 (1969). Diamond, however, did not reject the private claim in individual losing market traders. By itself, therefore, it creates the possibility of double liability, which has engendered considerable criticisin. E.g., Freenan v. Decio, 584 F.2d 186 (7th Cir. 1978); see generally R. Jennings \& R. BuXbaum, Corporations 605-11 (1979).

57. See also Note, supra note 18, at 285 \& n.82; Note, From Brophy to Scheim: Muddled Thinking, Excellent Result, 1 J. CORP. LAw 83, $92-93$ (1975).

58. 24 N.Y.2d at 499,248 N.E.2d at 912,301 N.Y.S.2d at $81-82$.

59. Id. at 498,248 N.E.2d at 912,301 N.Y.S.2d at 81.

60. Compare Schein v. Chasen, 478 F.2d 817 (2d Cir. 1973), vacated and remanded sub nom. Lehman Bros. v. Schein, 416 U.S. 386 (1974) with Freeman v. Decio, 584 F.2d 186 (7th Cir. 1978) and Schein v. Chasen, 313 So.2d 739 (Fla. 1975). The Diamond doctrine has some force when apphied to facts similar to those of Brophy v. Cities Serv. Co., 31 Del. Ch. 241, 70 A.2d 5 (1949). 
common law action for breach of fiduciary duty is not the best vehicle for the regulation of insider trading in the national securities markets: the appropriate remedy is a corporate cause of action under federal law. Such a federal statute need not espouse the controversial corporate asset theory of Diamond, which was necessary to bring the insiders' abuse within the domain of fiduciary liability under state law. Nor inust a federal statute require or even presuppose that insider trading injures the corporation. If the purpose of the remedy is deterrence, rather than compensation, it is relatively unimportant who is benefited by the inside trader's punishment. 61

Some nay argue that it can be unjust to permit a corporation to benefit from the wrongful acts of persons affiliated with it, ${ }^{62}$ but this reasoning assumes that compensation of losing market traders is the goal of insider trading regulation. The goals of deterrence, disgorgeinent, and pumshment are all equally served as long as someone brings the lawsuit against the insiders, no matter who is awarded the judgment. In theory, a corporate recovery benefits the corporation's current shareholders. Although these parties may have been spared the loss suffered by losing market traders, it is important to bear in mind that, unless the losing market traders were also induced traders, their injury was not caused by imsider trading where the corporation had a legitimate reason for secrecy. The benefit to the current shareholders from a corporate recovery inay be fortuitous, but it is no nore fortuitous than

In Brophy the inside information consisted of knowledge that the company was about to embark on a program of purchasing its own shares. An employee bought in anticipation of a resulting price rise. It appears that the price rise was caused by actual purchases by the company in the open market, and not simply by its announcement of intentions. Id. at $243,70 \mathrm{~A} .2 \mathrm{~d}$ at 7 . If this is true, the shares that the employee purchased at a lower price were shares the company could have purchased at that price had the employee abstained. On these facts, it is quite plausible to conclude that the company lost an amount equal to the employee's profit. Unfortunately, in the more typical fact situation, the inside information is not an asset that can bo used by the corporation to its pecuniary advantage without itself violating the securities laws, and here the misuse-of-a-corporate-asset theory has a rather inakeweight appearance. In particular, it becomes impossible to relate the amount of the insider's unfair profit to any damage supposedly suffered by the corporation. But of. Umited States v. Newman, 664 F.2d 12 (2d Cir. 1981) (purchase of target company shares by employees of investment banker representing acquiring company violates rule 10b-5 through employees' fraudulent breach of duty to their employer and its clients; O'Connor \& Assocs. v. Dean Witter Raynolds, Inc., 529 F.Supp. 1179 (S.D.N.Y. 1981) (relying on the breach of a Newman duty to the employer and its clients to find a rule 10b-5 claim against inside traders in losing market traders).

61. In the 50 years of its existence, section $16(b)$ las been subject to some rather severe criticism, see, e.g., FED. SEC. CODE $\$ 1714$ Comment 1 (1980), but little of it has been aimed at the section's creation of a corporate recovery absent any showing of larm to the eorporation.

62. For example, where the expense of proration is unwarranted, and if the award would not be "inequitable," a court may award the damages won in a FSC section 1704 suit to the corporation. FED. SEC. CODE \& I7II(j)(2) (1980). 
the benefit to most losing market traders who would recover under the FSC scheme. Furthermore, insofar as the corporation has an interest in discouraging trading by insiders, ${ }^{63}$ it has a special incentive to secure their punishment. ${ }^{64}$ When the offending insider is a director or an officer, the corporate action may be more likely to take the form of a shareholder's derivative suit rather than the form of a direct suit by the corporation for recovery of the unfair profit. In other cases, however, a direct suit seems quite likely even without shareholder prodding, and the degree of enforcement may in fact increase, because the board of directors is more likely than company outsiders to discover the illegal activity.

In the typical case under the FSC, individual small traders will recover only a nominal amount. Therefore, the apportioned-claim approach of the FSC relies significantly for its enforcement on the attorneys' fees incentive of a class action. ${ }^{65}$ The drafters apparently assume that, notwithstanding the limited recovery and the procedural obstacles, attorneys will be willing to bring the actions in the hope of recoverimg their fees out of the claim. The attorneys' fees imcentive is also important in a system that provides a corporate cause of action agamst inside traders. Such a system must rely substantially on private attorneys to "find" a shareholder who is antagomistic to management, and who will agree to institute a derivative action with attorneys' fees payable out of the corporate recovery. ${ }^{66}$ A derivative action created by federal statute, however, would not include the difficulties of notice, proof of claim, apportionment, and distribution that are inherent in the FSC approach, nor need it contain the procedural roadblocks of many state statutes. Moreover, where the board members have not been involved in the illegal trading, the procedures attendant to a derivative action may be avoided in a direct suit by the corporation.

Because the FSC approach and the corporate claim approach both rely heavily on the attorneys' fees imcentive, it does not seem likely that the former will achieve any greater degree of enforcement than the lat-

63. Though diffcult to ascertain, it is certainly possible that insider trading injures the corporation's reputation, as suggested in Diamond. See supra text accompanying note 58. In addition, insider trading might cause problems in the internal workings of a corporation, such as delays in internal communication of information, competition and distrust among employees with access to privileged information, and information distortion. Haft, The Effect of Insider Trading Rules on Internal Efficiency of the Large Corporations, 80 MICH. L. REV. 1501 (1982).

64. But see Dooley, supra note 1, at 44-46 (no general demand from corporations for the enforcement of insider trading regulations).

65. See Smolowe v. Delendo Corp., 136 F.2d 231, 241 (2d Cir.), cert. denied, 320 U.S. 751 (1943); FED. SEC. CODE § 1708(c) Comment 2 (1980).

66. See, e.g., Knauss, supra note 7, at 59; Note, supra note 18, at 298; Note, supra note 8, at 314; Comment, Pandora's Box, supra note 7, at 416 \& n.59. 
ter. Moreover, the corporate claim approach is not burdened by the procedural difficulties that accompany the individual class claim, nor will it ignite as much investor grumbling about the paucity of damages. In short, when msider trading takes place during a period in which the corporation has a legitimate business purpose for keeping the infornation secret, compensation of market losers is not an appropriate goal of the regulatory scheme and calmot be achieved by the class action approach of the FSC. A claim solely in the corporation to recover the amount of the imsider's unfair profit or some multiple thereof would serve the goals of deterrence, disgorgement, and punishment at least as well as the class action approach, without nearly as many untoward side effects.

\section{Regulation of Insider Trading When the Corporation Has No Legitimate Business NeEd for SeCrecy}

Insider trading in impersonal markets may also take place while the corporation unreasonably delays in making public the inforination on which the insider trades, that is, where the corporation has no legitimate business purpose for keeping the information secret, yet fails to release it. In this case, identifiable losing market traders are mjured, ${ }^{67}$ but it is the unreasonable nondisclosure rather than the insider trading that causes the injury. Had there been timely disclosure of the information, the market price would have adjusted to reflect its import, and the losses suffered by persons trading in the opposite direction from the insiders during the secrecy period would have been averted. Timely disclosure also effectively deters insider tradimg because the resultimg price adjustment eliminates the imsider's opportunity to profit. Therefore, unless the reason for nondisclosure is somehow related to the insider trading activity, analysis and resolution of the insider trading problem should refer to general disclosure requirements and not to a scheme specifically desigued to regulate insider trading.

There are two types of cases to consider. First is the case in which the nondisclosure is unrelated to insider trading. If, for example, inanagers with authority to disseminate new and material infornation fail, perhaps negligently, to disclose the information when there is no justifi-

67. Again, induced and preenpted traders are directly injured by the insider trading, but it is impossible to identify them. See supra text accompanying notes 10-11, and notes 28-30 and accompanying text. Moreover, preempted traders can hardly be heard to complain under these circumstances, because timely disclosure would have preempted them even sooner. Although the relative losses of winning market traders (lower gains) are also caused by the insider tradimg, see supra text accompanying note 26, and notes 32-34 and accompanying text, their gains, like the insiders', are also the result of the unreasonable nondisclosure. Under these circuinstances, there is no reason to.consider permitting a damages claim by winning market traders. 
able reason for secrecy, and a lower level employee, or even another manager who is privy to the information but is not authorized to disseminate it, ${ }^{68}$ trades on the information, no identifiable market loser is harmed by the insider trading. As is the case when the corporation has a legitimate reason for secrecy, the harm is caused by the corporation's nondisclosure.

In the second type of case, secrecy is mamtained for the purpose of profiting through insider trading. Where officers or others im the coinpany have authority to disclose material corporate information, but keep the information secret and trade on it, ${ }^{69}$ it is not unreasonable to conclude that the reason for nondisclosure is to permit profiteering in securities transactions. ${ }^{70}$ In this case, the nondisclosure is inextricably linked with the insider trading activity: the decision to engage in imsider trading causes the nondisclosure, and the nondisclosure causes the injury to losing market traders.

In either case, losing inarket traders suffer a loss. In the first case, however, the corporation's nondisclosure causes the loss, while in the second case, the decision to engage in insider trading causes the loss. It follows from this distinction that two kinds of reinedies are appropriate. Where the nondisclosure is unrelated to insider trading, the remedy, if any, must be under the general disclosure provisions and against the corporation or its wrongfully acting manager(s) who caused the injury, rather than against the insider who traded. Reaping an unfair profit is the insider's wrong; as demonstrated above, ${ }^{71}$ that wrong is appropriately remedied by a claim in the corporation agamst the insider for the amount of his profit, and perhaps some extra to teach him a lesson. Market traders always take the risk that corporate inanagers will not be doing their jobs correctly and on certain occasions may even be breaking the law. If the failure to disclose injurcs identifiable trad-

68. This type of case would encompass all instances of insider trading by persons who are outside the formal corporate structure but who nevertheless have access to privileged information.

69. For discussion of the distinction between a general duty in the corporation to disclose and the obligation to abstain from trading of a person who does not have responsibility for disseminating corporate information, see Comment, Civil Liability, supra note 19, at 676-77.

70. Brudney, supra note 21, at 328; see State Teachers Retirement Bd. v. Fluor Corp., 500 F. Supp. 278, 294 (S.D.N.Y. 1980) (wrongful purpose may be inferred from a showing that defendant acted for personal gain), modified on other grounds, 654 F.2d 843 (2d Cir. 1981); Cominent, Civil Liability, supra note 19, at 677 (busimess judgment rule on timing of disclosure difficult to overcome unless self-profit motives are present); $c f$. SEC v. Texas Gulf Sulphur Co., 258 F. Supp. 262, 293-94 (S.D.N.Y. 1966) (liability under rule 10b-5 results from issuing false press release for purpose of affecting market price to personal advantage but such purpose must be shown), rev'd, 401 F.2d 833 (2d Cir. 1968), cert. denied, 394 U.S. 976 (1969).

71. See supra text accompanying notes 53-64. 
ers, there should perhaps be a legal remedy, ${ }^{72}$ but this has nothing to do with the regulation of insider trading.

On the other hand, if the nondisclosure is directly caused by an msider's decision to trade and profit on the secret information, the decision to engage in insider trading causes the losing market traders' losses. The appropriate remedy is, arguably, to permit individual claims for coinpensatory damages. If compensation for such losses is an appropriate goal, however, there is no reason in theory to limit the total amount of the claim to the insider's illegal profit, as does the FSC. The insider willfully commits a wrongful act that causes heavy losses to identifiable investors-those who traded durimg the period in which the information was wrongfully withheld. The mvestors therefore should be compensated by the insider for the total amount of their losses. Moreover, rapid public disclosure is a goal in these circumstances because the sooner the information becoines public knowledge, the fewer innocent market traders will suffer losses. Because the magnitude of the individual injuries and the number of traders injured will continue to increase until the information is publicly released, hability for the full amount of the ever-growing losses should be a strong incentive to the insiders to release the information as soon as possible after effecting their transactions.

Nevertheless, the practical implementation of a full compensation statute poses serious problems. Actual dannages to be paid by the insiders will often be huge, amounting to many times their illegal profits. Judges can be expected to rebel in cases where the insider's wrongful act, somehow, does not look as bad as these extreinely heavy penalties would imply. More important, liability will depend on the issie of whether there was a justifiable business reason for secrecy, because where nondisclosure was justified, all identifiable losses are attributable simply to ordinary investment risks, not to insider trading. In that case compensation is irrelevant. ${ }^{73}$ As useful as the busmess-reason-for-secrecy test is conceptually, it is often very difficult in practice to determine whether nondisclosure is justified or abusive..$^{74}$ Nor will it be clear in many cases whether the inside trader was authorized to disclose the information, even absent a justifiable reason for secrecy. It is sound jurisprudence to avoid inaking such huge liability turn on the resolu-

72. Whether the existing disclosure rules and the remedies for noncompliance with them provide adequate investor protection is a serious problem that lias yet to be fully resolved. For discussion of the use of rule 10b-5 to require prompt disclosure of material information, see generally Bauman, supra note 23; Comment, supra note 23.

73. See supra text accompanying notes 25-35.

74. See supra note 23 and accompanying text. 
tion of these vague questions. Although the danger of strike suits is often overemphasized, they can surely be expected to increase in number with the size of the potential recovery, especially when the elements of the key issues are unclear. ${ }^{75}$ In the hands of courts unwilling to levy such heavy damages, the substantive issues ${ }^{76}$ would grow increasimgly murky, making the law arbitrary and uneven in its application. Moreover, fear of incurring such heavy hability could easily lead to the premature release of information by managers seeking to protect themselves, which might imjure the corporation. ${ }^{77}$ These practical considerations argue for some limitation on damages even when the insider's decision to trade has caused actual mjury to identifiable market traders.

Limiting total damages, however, to the amount of the imsider's unfair profit or some multiple thereof, as the drafters of the FSC have done, impticitly admits that compensation of injured parties is no longer the primary goal of the system. Any such limitation is necessarily arbitrary ${ }^{78}$ and is in no way related to the amount of actual injury suffered. Of course, the apportioned damages approach of the FSC does award the losers something, which, all other things being equal, seems better than nothing. But in fact all other things are not equal. Where the insider trading has actually caused the losing market traders' losses, the losers will have all the more reason to be bitter over their miniscule recovery. Involving them in a class action that brings high profits to the attorneys and otherwise only reemphasizes the plaintiff's losses by awarding them a small fraction of their actual damages can be expected to generate only cynicism and disdam. If the compensation principle is to be denied, it seems best to deny it completely.

There is yet another reason to avoid a full compensation, individual-recovery scheme. The scheme's draconian liability arises from the fact that the insider does not garner the bulk of the total profits earned as a result of the nondisclosure. All winning market traders, who trade in the same direction as the insider, will profit with him, although the market winners do not realize when they trade that news favorable to

75. See Comment, Civil Liability, supra note 19 , at 678.

76. These issues include: who within the corporation is authorized to disclose what types of information; who is a proper plaintiff; what information is material; at what point is information public; whether rehance is necessary; whether motivation defenses are appropriate; and what constitutes a justifiable reason for secrecy.

77. Another problem that might be expected to arise from a full compensation approach is a reduction of share ownership by corporate insiders. Note, supra note 8 , at 308 ; Comment, Civil Liability, supra note 19, at 678. But see Diamond v. Oreamuno, 24 N.Y.2d 494, 499, 248 N.E.2d 910, 913, 301 N.Y.S.2d 78, 82 (1969).

78. Pozen, supro note 40 , at 364 . 
their transaction is imminent. While it is true that the winning market traders do not gain as much as is lost by the market losers (the difference being the amount of the unfair profit reaped by the insider), it is nevertheless possible to view as an ordinary trading risk the chance that an investor's purchase or sale inay occur at a time when material information that should have been disclosed has not yet been made public. If it is true that insider profits are usually only a sinall percentage of the winning inarket traders' total profit, the outside winners' gains will equal a high percentage of the losing inarket traders' losses. This inakes it look very inuch like an investinent-risk injury. There will be soine winners and some losers, with outsiders generally losing inore often than they win because the knowledgeable insiders are always trading in the profitable direction. Yet, the risk of loss is not radically different from other kinds of investment risk. Therefore, one might justifiably hesitate to invite the jurisprudential problems implied by a full compensation sclieine, even when insiders trade absent a legitimate business purpose for corporate secrecy. The regulatory scheme covering insider trading can avoid all the practical and theoretical problems attendant to a full compensation approacli if it simply gives to the corporation the sole claim for disgorgement of the illegal profit, or soine inultiple thereof, in all cases. Liability in this amount is necessary and desirable because the profit is unfair and the trading activity illegal whether or not there is good reason for secrecy. The problem of prompt disclosure when there is a good reason for secrecy, and the penalties for failing to disclose promptly, are best covered by general disclosure provisions, since inarket traders are equally harmed by unreasonable nondisclosure whether or not insiders have traded.

\section{ConClusion}

It is incorrect to say that compensation of innocent market traders is never a legitimate goal of a scheme regulating insider trading activities. Injured parties whose losses are causally related to the illegal insider trading can be easily identified. Such identifiable injuries, however, are limited to cases in which insiders have traded while deliberately and unjustifiably withholding inaterial information, and in this case, the inore fundamental problein is disclosure, not insider trading. Moreover, even where it is theoretically warranted, compensation raises inany practical difficulties.

The vast inajority of insider trading cases occur when the corporation does have a legitimate purpose for keeping the information secret. In such cases, compensation is unwarranted because insider trading activity causes no damage to any identifiable market traders. Therefore, it 
seems best to treat all insider trading activity as a moral wrong that should be deterred and punished. Problems concerning corporate disclosure should be left to those provisions of the regulatory scheme that deal directly with disclosure duties, and private rights of action in individual investors for damages from insider trading should be expressly denied. The sole private claim-for the amount of the insider's unfair profit plus such additional amounts or inultiples thereof as are deened necessary. for an adequate balance of deterrence and punishmentshould be recognized in the corporation whose securities are the subject of the illegal trading activity. 
